\title{
Periode Kritis Pertumbuhan Kedelai Hitam (Glycine max (L.) Merr) dalam Berkompetisi dengan Gulma
}

The Critical Period for the Growth of Black Soybean (Glycine max (L.) Merr) in Competition with Weeds

\author{
Sandry Gultom, Sofyan Zaman" dan Heni Purnamawati
}

Departemen Agronomi dan Hortikultura, Fakultas Pertanian, Institut Pertanian Bogor

(Bogor Agricultural University), Jl. Meranti, Kampus IPB Darmaga, Bogor 16680, Indonesia

Telp.\&Faks. 62-251-8629353 e-mail agronipb@indo.net.id

*Penulis untuk korespondensi : sofyanzaman@yahoo.co.id

Disetujui 16 Januari 2017 / Published Online 24 Januari 2017

\begin{abstract}
The critical period of the competition with weeds into consideration in determining when is the right time to control weeds and appropriate action taken to manage weeds.The experiment was carried out at the Sawah Baru field Experiment, Dramaga, Bogor Agricultural University, Bogor, altitude of 209 meters above sea level from April-July 2016.The environmental design used was the Randomized Complete Block Design with 12 levels of treatment with three replications. The levels of treatment consists of clean weeds and weeds $(0-2,0-4,0-6,0-8,0-10,0$-harvest) weeks after planting. Weeding was done manually and the time is adjusted adjusted with the treatment period for each patch of weed competition. Based on the research results, the critical period of black soybeans Mallika is 2-6 weeks after planting with the loss of the crops of early planting to the harvest obtained ranges between $23.61 \%$ to $83.54 \%$.
\end{abstract}

Key words :competition, the lost of the crops, weeding

\begin{abstract}
ABSTRAK
Periode kritis terhadap persaingan dengan gulma menjadi pertimbangan dalam menentukan kapan saat yang tepat untuk mengendalikan gulma dan tindakan yang tepat dilakukan untuk melakukan pengelolaan gulma. Percobaan dilaksanakan di Kebun Percobaan Sawah Baru, Institut Pertanian Bogor, Dramaga, Bogor dengan ketinggian tempat 209 meter diatas permukaan laut pada bulan April-Juli 2016. Rancangan lingkungan yang digunakan adalah rancangan kelompok lengkap teracak dengan 12 taraf perlakuan dengan tiga ulangan. Taraf perlakuan terdiri atas bersih gulma dan bergulma (0-2 MST, 0-4 MST, 0-6 MST, 0-8 MST, 0-10 MST, 0-panen). Penyiangan gulma dilakukan secara manual dan waktunya disesuaikan dengan perlakuan periode kompetisi gulma untuk setiap petak. Berdasarkan hasil penelitian, periode kritis kedelai hitam Mallika adalah 2-6 MST dengan kehilangan hasil panen dari awal tanam hingga panen diperoleh berkisar antara $23.61 \%$ hingga $83.54 \%$.
\end{abstract}

Kata kunci : penyiangan gulma, persaingan, kehilangan hasil 


\section{PENDAHULUAN}

Gulma adalah tumbuhan yang tumbuh tidak pada tempatnya yang dapat merugikan tanaman budidaya sehingga manusia berusaha untuk mengendalikannya. Kerugian yang ditimbulkan di bidang usaha tani adalah menurunkan hasil, menurunkan mutu, dan menambah biaya produksi (Sembodo, 2010). Faktor utama dalam kompetisi tanaman dan gulma untuk memperoleh sumber daya yang tersedia seperti air, unsur hara, dan cahaya serta ruang tumbuh.

Periode kritis adalah suatu keadaan dimana tanaman sangat sensitif terhadap kompetisi dengan gulma (Moenandir, 2010). Periode kritis atau masa rentan terhadap persaingan dengan gulma menjadi pertimbangan dalam menentukan kapan saat yang tepat untuk mengendalikan gulma dan tindakan yang tepat dilakukan untuk melakukan pengendalian gulma. Pengendalian gulma merupakan upaya manusia dalam menangani gulma sehingga tidak menimbulkan kerugian bagi manusia (Sembodo, 2010).

Periode kritis tanaman terhadap persaingan dengan gulma merupakan salah satu langkah yang penting dalam menyusun rencana kapan pengendalian yang tepat dilakukan agar tidak menimbulkan kerugian hasil. Penelitian ini bertujuan untuk mengetahui periode kritis pertumbuhan tanaman kedelai hitam dalam berkompetisi dengan gulma.

\section{METODE PENELITIAN}

Penelitian dilaksanakan di Kebun Percobaan IPB Sawah Baru, Dramaga, Kabupaten Bogor dengan ketinggian tempat $209 \mathrm{~m}$ dpl. Penelitian ini dilaksanakan pada bulan April-Juli 2016. Bahan tanaman yang digunakan adalah kedelai hitam varietas Mallika. Bahan lainnya yang digunakan adalah pupuk Urea, SP-36, dan $\mathrm{KCl}$, rhizobium inokulan Nodulin. Peralatan yang digunakan antara lain alat budidaya, alat tulis kantor, timbangan digital, oven listrik, amplop coklat, ajir, meteran serta kuadrat berukuran $0.5 \mathrm{~m}$ $\mathrm{x} 0.5 \mathrm{~m}$.

Penelitian ini menggunakan rancangan kelompok lengkap teracak (RKLT) yang terdiri dari satu perlakuan yaitu periode kompetisi gulma. Periode kompetisi gulma terdiri atas 12 taraf yaitu: bersih gulma dan bergulma (0-2 MST, 0-4 MST, 0-6 MST, 0-8 MST, 0-10 MST, 0panen). Perlakuan bersih gulma 0-panen digunakan sebagai kontrol. Setiap perlakuan diulang sebanyak tiga kali sehingga terdapat 36 satuan percobaan.

Penelitian diawali dengan melakukan analisis kesuburan tanah, kemudian lahan diolah dan dibuat petakan berukuran $3 \mathrm{~m}$ x $2.5 \mathrm{~m}$ dengan jarak antar petak $100 \mathrm{~cm}$ dan jarak antar ulangan $100 \mathrm{~cm}$. Benih kedelai hitam ditanam dengan jarak tanam $25 \mathrm{~cm} \times 20 \mathrm{~cm}$ dengan cara tugal sebanyak 1 butir per lubang. Sebelum dilakukan penanaman, benih kedelai hitam diinokulasi dengan rhizobium inokulan Nodulin (biakan murni rhizobium) sebanyak $5 \mathrm{~g} \mathrm{~kg}^{-1}$ benih dengan cara membasahi benih kedelai hitam dengan air lalu menaburkan inokulan secara merata pada benih. Pemupukan dilakukan bersamaan dengan penanaman dengan cara aplikasi di tugal. Benih yang tidak tumbuh kemudian disulam pada saat 710 hari setelah tanam (HST).

Pemeliharaan tanaman meliputi penyiraman dan penyemprotan insektisida. Penyiraman tanaman kedelai hitam dilakukan saat tanaman kedelai hitam Mallika berumur 5 MST-8 MST atau saat tidak turun hujan. Penyemprotan insektisida dilakukan ketika mulai terlihat gejala serangan awal hama dan penyakit. Pemanenan dilakukan pada saat tanaman telah berumur 12 MST atau saat $80 \%$ daun kedelai hitam sudah menguning.

Peubah yang diamati meliputi tinggi tanaman, jumlah daun, jumlah cabang, jumlah bintil akar, saat $75 \%$ dari populasi berbunga, indeks luas daun, bobot kering tajuk tanaman, jumlah polong isi dan hampa, bobot 100 butir biji, bobot biji kering pada saat panen, bobot kering biomassa, hasil panen ubinan, persen penutupan gulma total, biomassa gulma total. Data hasil penelitian dianalisis dengan sidik ragam menggunakan uji F. Jika perlakuan menunjukan pengaruh nyata terhadap peubah yang diamati, maka dilakukan uji lanjut menggunakan $T$ dunnett.

\section{HASIL DAN PEMBAHASAN}

\section{Kondisi Umum}

Curah hujan rata-rata selama penelitian dari bulan April hingga Juli 2016 adalah 558.2 $\mathrm{mm} ; 329.7 \mathrm{~mm} ; 373.0 \mathrm{~mm}$; dan $292.5 \mathrm{~mm}$ (BMKG, 2016). Curah hujan yang optimum untuk tanaman kedelai berkisar $200 \mathrm{~mm}$ per bulan (Sumarno dan Manshuri, 2007). Menurut data BMKG (2016), suhu rata-rata lingkungan selama pertanaman kedelai adalah $26.35^{\circ} \mathrm{C}$. Menurut Adie dan Krisnawati (2007) bahwa suhu tersebut sesuai dengan pertanaman kedelai adalah 25$27^{\circ} \mathrm{C}$. 
Hasil analisis tanah yang dilakukan menunjukkan bahwa lahan penelitian memiliki tekstur lempung liat berdebu dengan $\mathrm{C} / \mathrm{N}$ rasio adalah 18.31 yang termasuk dalam kategori tinggi. Lahan penelitian yang digunakan memiliki $\mathrm{pH}$ masam yakni 5.42 sedangkan $\mathrm{pH}$ tanah yang baik untuk pertumbuhan kedelai 5.8-7 (BKPP, 2009).

Hama yang menyerang tanaman kedelai selama penelitian adalah lalat buah (Ophiomya phaseoli), kepik hijau (Nezara viridula), ulat penggerek polong kedelai (Etiella zinckenella), kepik penghisap polong kedelai (Riptortus linearis) dan kutu daun (Aphis glycine). Penyakit yang menyerang tanaman kedelai adalah bercak daun, virus mozaik kedelai (Soybean mosaic virus) dan busuk daun yang disebabkan oleh jamur Sclerotium rolfsii. Serangan OPT tersebut tidak menimbulkan kerugian yang cukup besar.

Tabel 1. Rekapitulasi hasil sidik ragam periode kritis petumbuhan kedelai hitam dalam berkompetisi dengan gulma

\begin{tabular}{|c|c|c|c|c|}
\hline Variabel & MST & KT & F value & $\mathrm{KK}(\%)$ \\
\hline \multirow[t]{6}{*}{ Tinggi Tanaman } & 2 & 0.54 & $0.87^{\mathrm{tn}}$ & 9.50 \\
\hline & 3 & 3.30 & $2.91^{\mathrm{tn}}$ & 8.40 \\
\hline & 4 & 4.19 & $1.44^{\mathrm{tn}}$ & 8.48 \\
\hline & 5 & 8.01 & $1.10^{\mathrm{tn}}$ & 8.17 \\
\hline & 6 & 15.85 & $1.69^{\mathrm{tn}}$ & 7.32 \\
\hline & 7 & 88.98 & $2.09^{\mathrm{tn}}$ & 10.48 \\
\hline \multirow[t]{6}{*}{ Jumlah daun } & 2 & 0.03 & $0.61^{\text {tn }}$ & 18.29 \\
\hline & 3 & 0.08 & $0.45^{\mathrm{tn}}$ & 10.73 \\
\hline & 4 & 1.36 & $1.48^{\text {tn }}$ & 10.73 \\
\hline & 5 & 36.21 & $4.46^{* *} *$ & 23.49 \\
\hline & 6 & 86.95 & $9.11 * *$ & 20.01 \\
\hline & 7 & 300.55 & $11.25^{* *}$ & 18.99 \\
\hline \multirow[t]{4}{*}{ Jumlah cabang } & 4 & 0.23 & $1.86^{\mathrm{tn}}$ & 10.26 \\
\hline & 5 & 4.71 & $6.42 * *$ & 5.70 \\
\hline & 6 & 9.01 & $16.67 * *$ & 18.56 \\
\hline & 7 & 9.57 & $23.85^{* *}$ & 13.60 \\
\hline Jumlah bintil akar & 4 & 10.11 & $0.84^{\mathrm{tn}}$ & 7.08 \\
\hline Indeks luas daun & 7 & 0.43 & $1.36^{\mathrm{tn}}$ & 6.65 \\
\hline Waktu berbunga & $4-5$ & 8.97 & $6.27 * *$ & 2.86 \\
\hline \multirow[t]{3}{*}{ Bobot kering tajuk kedelai } & 4 & 1.16 & $0.71^{\text {tn }}$ & 9.38 \\
\hline & 8 & 24.87 & $1.18^{\mathrm{tn}}$ & 5.70 \\
\hline & 12 & 18.68 & $2.37 *$ & 8.72 \\
\hline \multirow[t]{3}{*}{ Bobot kering akar kedelai } & 4 & 0.03 & $0.82^{\text {tn }}$ & 10.30 \\
\hline & 8 & 0.76 & $2.38 *$ & 5.87 \\
\hline & 12 & 0.70 & $2.47 *$ & 6.90 \\
\hline Jumlah polong isi & $12-14$ & 121548.06 & $3.89 * *$ & 13.31 \\
\hline Jumlah polong hampa & $12-14$ & 7103.36 & $0.81^{\text {tn }}$ & 8.76 \\
\hline Bobot 100 butir & 14 & 0.87 & $0.97^{\mathrm{tn}}$ & 10.10 \\
\hline Bobot kering biji & 14 & 2939.28 & $16.58 * *$ & 21.52 \\
\hline Hasil panen $1,5 \mathrm{~m}^{2}$ & 14 & 10368.01 & $9.90 * *$ & 27.39 \\
\hline
\end{tabular}

Keterangan : **=berpengaruh sangat nyata pada taraf $\alpha=5 \%, *=$ berpengaruh nyata pada taraf $\alpha=5 \%$ MST=minggu setelah tanam, $\mathrm{tn}=$ tidak nyata, $\mathrm{KT}=$ kuadrat tengah, $\mathrm{KK}=$ koefisien keragaman.

\section{Tinggi Tanaman}

Periode bersih gulma 0-panen (kontrol) tidak memberikan pengaruh yang berbeda nyata terhadap tinggi tanaman pada periode bersih gulma (0-2 MST, 0-4 MST, 0-6 MST, 0-8 MST, dan 0-10 MST) dan periode bergulma (0-2 MST, 0-4 MST, 0-6 MST, 0-8 MST, 0-10 MST, dan 0panen). Tidak adanya perbedaan tinggi tanaman dapat terjadi karena persaingan antara tanaman kedelai dan gulma belum terjadi. Menurut Sembodo (2010), persaingan antara gulma dan tanaman terjadi dalam perebutan faktor tumbuh seperti ruang tumbuh, cahaya, air nutrisi, $\mathrm{CO}_{2}$ dan bahan lainnya. Persaingan antara tanaman dan gulma dapat terjadi bila faktor tumbuh tanaman yang dibutuhkan berada dibawah kebutuhan.Ukuran tinggi tanaman kedelai hitam pada 2-7 MST berkisar antara 7.61-73.00 cm. Menurut Permentan (2007) kedelai hitam varietas Mallika memiliki tinggi sebesar $60-80 \mathrm{~cm}$.

\section{Jumlah Daun}

Perlakuan kontrol memberikan pengaruh yang berbeda nyata terhadap jumlah daun pada 
areal bergulma (0-6 MST, 0-8 MST, 0-10 MST, dan 0-panen) saat kedelai hitam berumur 6-7 MST. Perlakuan bergulma 0-panen memiliki jumlah daun yang terendah jika dibandingkan dengan periode penyiangan gulma lainnya (Tabel 2) karena menurut Eprim (2006) semakin lama gulma berada pada areal pertanaman akan mengakibatkan jumlah daun semakin berkurang. Persaingan antara gulma dan tanaman kedelai semakin meningkat dalam mendapatkan faktor tumbuh yang dibutuhkan untuk pertumbuhan daun tersebut.

Tabel 2. Jumlah daun kedelai hitam Mallika pada periode kritis pertumbuhan kedelai hitam dalam berkompetisi dengan gulma

\begin{tabular}{|c|c|c|c|c|c|c|}
\hline \multirow{2}{*}{ Perlakuan } & \multicolumn{6}{|c|}{ MST } \\
\hline & 2 & 3 & 4 & 5 & 6 & 7 \\
\hline Bersih Gulma 0-panen (kontrol) & 1.39 & 3.94 & 6.33 & 14.45 & 18.28 & 36.33 \\
\hline Bersih Gulma 0-2 MST & 1.50 & 4.33 & 7.49 & 13.28 & 18.06 & 28.50 \\
\hline Bersih Gulma 0-4 MST & 1.33 & 4.06 & 6.56 & 15.00 & 19.55 & 34.89 \\
\hline Bersih Gulma 0-6 MST & 1.50 & 4.11 & 6.89 & 16.78 & 20.55 & 33.72 \\
\hline Bersih Gulma 0-8 MST & 1.33 & 4.05 & 6.55 & 16.67 & 20.67 & 42.78 \\
\hline Bersih Gulma 0-10 MST & 1.33 & 3.95 & 6.39 & 14.67 & 21.22 & 26.78 \\
\hline Bergulma 0-2 MST & 1.39 & 3.67 & 6.28 & 12.11 & 17.83 & 33.89 \\
\hline Bergulma 0-4 MST & 1.50 & 4.04 & 5.38 & 10.28 & 14.89 & 30.44 \\
\hline Bergulma 0-6 MST & 1.11 & 3.83 & 5.45 & 7.54 & $8.00 \mathrm{a}$ & $14.33 \mathrm{a}$ \\
\hline Bergulma 0-8 MST & 1.50 & 3.89 & 5.45 & 8.10 & $8.61 \mathrm{a}$ & $14.52 \mathrm{a}$ \\
\hline Bergulma 0-10 MST & 1.33 & 4.06 & 5.67 & 8.61 & $10.05 \mathrm{a}$ & $16.33 \mathrm{a}$ \\
\hline Bergulma 0-panen & 1.44 & 3.89 & 5.49 & 8.11 & $7.50 \mathrm{a}$ & $14.06 \mathrm{a}$ \\
\hline
\end{tabular}

Keterangan : Angka yang diikuti dengan huruf a berbeda nyata dengan perlakuan bersih gulma 0-panen (kontrol) berdasarkan hasil $T$-dunnett pada taraf $\alpha=5 \%$, MST = minggu setelah tanam.

\section{Jumlah Cabang}

Jumlah cabang dipengaruhi setelah gulma berada pada areal bergulma (0-6MST, 0-8MST, 010MST, dan 0-panen) sehingga berbeda nyata terhadap perlakuan kontrol. Tabel 3 menunjukkan bahwa cabang kedelai mulai terbentuk pada minggu ke-5 sehingga gulma tidak memberikan pengaruh yang berbeda nyata pada periode bersih gulma (0-2 MST, 0-4 MST, 0-6 MST, 0-8 MST, dan 0-10 MST) dan periode bergulma (0-2 MST dan 0-4 MST) terhadap perlakuan kontrol.
Pertumbuhan gulma pada areal bergulma 0-4 MST masih lambat dan tajuk antar tanaman mulai saling menutupi areal pertanaman sehingga kompetisi dalam penggunaan faktor sarana tumbuh belum tinggi. Gulma yang semakin lama berada dalam areal pertanaman kedelai maka akan mengakibatkan semakin sedikitnya jumlah cabang yang terbentuk. Terhambatnya pembentukan cabang kedelai ini disebabkan karena kebutuhan faktor sarana tumbuh yang semakin terbatas sehingga terjadi kompetisi antara gulma dan kedelai hitam.

Tabel 3. Jumlah cabang kedelai hitam Mallika pada periode kritis pertumbuhan kedelai hitam dalam berkompetisi dengan gulma

\begin{tabular}{lccc}
\hline & Perlakuan & \multicolumn{2}{c}{ MST } \\
\cline { 2 - 4 } Bersih Gulma 0-panen (kontrol) & 5 & 6 & 5.89 \\
Bersih Gulma 0-2 MST & 3.83 & 4.83 & 6.06 \\
Bersih Gulma 0-4 MST & 3.06 & 4.72 & 6.05 \\
Bersih Gulma 0-6 MST & 3.61 & 5.22 & 5.94 \\
Bersih Gulma 0-8 MST & 3.72 & 5.17 & 6.17 \\
Bersih Gulma 0-10 MST & 3.89 & 5.84 & 5.61 \\
Bergulma 0-2 MST & 4.00 & 5.45 & 5.50 \\
Bergulma 0-4 MST & 3.33 & 4.89 & 5.61 \\
Bergulma 0-6 MST & 2.22 & 4.78 & $2.22 \mathrm{a}$ \\
Bergulma 0-8 MST & $1.03 \mathrm{a}$ & $1.44 \mathrm{a}$ & $2.44 \mathrm{a}$ \\
Bergulma 0-10 MST & $0.94 \mathrm{a}$ & $1.78 \mathrm{a}$ & $2.55 \mathrm{a}$ \\
Bergulma 0-panen & $1.39 \mathrm{a}$ & $2.11 \mathrm{a}$ & $1.83 \mathrm{a}$ \\
\hline Kerangan : Anga
\end{tabular}

Keterangan : Angka yang diikuti dengan huruf a berbeda nyata dengan perlakuan bersih gulma 0-panen (kontrol) berdasarkan hasil $T$-dunnett pada taraf $\alpha=5 \%$, MST = minggu setelah tanam. 


\section{Jumlah Bintil Akar}

Perlakuan kontrol memberikan pengaruh yang berbeda nyata terhadap jumlah bintil akar aktif pada semua perlakuan periode penyiangan gulma (Tabel 4). Oleh karena itu, bintil akar dapat dipengaruhi oleh adanya gulma yang tumbuh di areal pertanaman sehingga gulma harus dikendalikan sejak pertanaman. Perlakuan kontrol memberikan pengaruh yang berbeda nyata terhadap jumlah bintil akar total pada periode semua perlakuan periode penyiangan gulma kecuali pada periode bergulma 0-panen memiliki banyak bintil akar yang tidak aktif. Menurut Inawati (2000) kehadiran gulma Cyperus rotundus mampu menekan jumlah bintil akar kedelai karena bakteri yang terdapat pada bintil akar memerlukan unsur $\mathrm{P}$ yang cukup tinggi untuk membentuk bintil akar sedangkan Cyperus rotundus lebih kuat dalam menyerap unsur $\mathrm{P}$ dibandingkan dengan gulma golongan lainnya. Unsur $\mathrm{P}$ dibutuhkan tanaman dalam proses pembungaan, pembuahan, pengisian polong dan perkembangan akar. Penekanan terhadap jumlah bintil akar oleh gulma disebabkan akibat terjadi ketidakseimbangan dalam penyerapan unsur hara dimana pada saat pembentukan bintil akar, tanaman kedelai juga membutuhkan unsur $\mathrm{P}$ dalam fase generatifnya.

\section{Umur Berbunga}

Umur berbunga ditentukan saat $75 \%$ dari populasi sudah berbunga. Tanaman kedelai hitam Mallika akan semakin lama berbunga saat gulma sudah berada di areal pertanaman 0-8 MST, 0-10 MST, dan 0-panen. Umur berbunga kedelai hitam Mallika (Tabel 4) berkisar antara 40.00-45.60 hari setelah tanam. Menurut Permentan (2007) kedelai hitam Mallika memiliki umur berbunga 36 hari setelah tanam.

\section{Indeks Luas Daun (ILD)}

Periode bersih gulma 0- panen (kontrol) tidak memberikan pengaruh yang berbeda nyata terhadap indeks luas daun pada periode bersih gulma (0-2 MST, 0-4 MST, 0-6 MST, 0-8 MST, dan 0-10 MST) dan periode bergulma (0-2 MST, 0-4 MST, 0-6 MST, 0-8 MST, 0-10 MST, dan 0panen). Indeks luas daun (ILD) berkisar antara 0.78-1.71 (Tabel 4). Menurut Eprim (2006) tanaman yang masih mampu untuk memanfaatkan faktor sarana tumbuh secara optimal maka pertambahan luas daun kedelai tidak terhambat. Keberadaan gulma pada awal pertumbuhan berada pada fase lambat mengakibatkan kepadatan populasi gulma sedikit sehingga gulma tidak memberikan pengaruh terhadap jumlah daun trifoliet kedelai.

Tabel 4. Jumlah bintil akar aktif, bintil akar total, waktu berbunga, indeks luas daun kedelai hitam Mallika pada periode kritis pertumbuhan kedelai hitam dalam berkompetisi dengan gulma

\begin{tabular}{lcccc}
\hline \multicolumn{1}{c}{ Perlakuan } & $\begin{array}{c}\text { Bintil akar } \\
\text { aktif }\end{array}$ & $\begin{array}{c}\text { Bintil akar } \\
\text { total }\end{array}$ & $\begin{array}{c}\text { Waktu berbunga } \\
\text { (hari) }\end{array}$ & $\begin{array}{c}\text { Indeks luas } \\
\text { daun }\end{array}$ \\
\hline Bersih Gulma 0-panen (kontrol) & 34.67 & 36.33 & 40.00 & 1.66 \\
Bersih Gulma 0-2 MST & $9.33 \mathrm{a}$ & $11.00 \mathrm{a}$ & 40.33 & 1.97 \\
Bersih Gulma 0-4 MST & $10.33 \mathrm{a}$ & $14.00 \mathrm{a}$ & 41.67 & 1.30 \\
Bersih Gulma 0-6 MST & $19.67 \mathrm{a}$ & $15.67 \mathrm{a}$ & 41.00 & 1.67 \\
Bersih Gulma 0-8 MST & $10.00 \mathrm{a}$ & $14.67 \mathrm{a}$ & 40.00 & 1.15 \\
Bersih Gulma 0-10 MST & $10.00 \mathrm{a}$ & $13.00 \mathrm{a}$ & 40.00 & 1.30 \\
Bergulma 0-2 MST & $3.67 \mathrm{a}$ & $4.67 \mathrm{a}$ & 41.67 & 0.78 \\
Bergulma 0-4 MST & $6.67 \mathrm{a}$ & $9.00 \mathrm{a}$ & 41.00 & 1.07 \\
Bergulma 0-6 MST & $7.00 \mathrm{a}$ & $8.67 \mathrm{a}$ & 42.67 & 1.04 \\
Bergulma 0-8 MST & $11.67 \mathrm{a}$ & $12.00 \mathrm{a}$ & $43.33 \mathrm{a}$ & 0.93 \\
Bergulma 0-10 MST & $6.33 \mathrm{a}$ & $8.67 \mathrm{a}$ & $45.60 \mathrm{a}$ & 0.90 \\
Bergulma 0-panen & $13.33 \mathrm{a}$ & 18.33 & $44.33 \mathrm{a}$ & 1.71 \\
\hline Keterangan : Anga & $\mathrm{y}$ &
\end{tabular}

Keterangan : Angka yang diikuti dengan huruf a berbeda nyata dengan perlakuan bersih gulma 0-panen (kontrol) berdasarkan hasil $T$-dunnett pada taraf $\alpha=5 \%$, MST $=$ minggu setelah tanam.

\section{Bobot Kering Tajuk Kedelai}

Perlakuan kontrol memberikan pengaruh yang berbeda nyata terhadap bobot kering tajuk pada periode bergulma 0 -panen pada saat tanaman kedelai berumur 8 MST (Tabel 5). Menurut Manshuri (1995) bobot kering tanaman merupakan kemampuan tanaman menyerap cahaya dan memiliki korelasi yang positif dengan laju fotosintesis yang dipengaruhi oleh kondisi lingkungan (hara, air, iklim dan cahaya). Tanaman akan memberikan hasil yang optimal apabila kondisi lingkungan di sekitar tanaman cukup akan hara, air, dan terhindar dari hama dan penyakit. 
Menurut Sumarno dan Manshuri (1999) tanaman kedelai pada umur 8 MST berada pada fase R6 (polong pada batang utama berisi biji berwarna hijau yang telah memenuhi rongga polong dan besar biji mencapai maksimum), namun pada periode bergulma 0-panen tanaman kedelai berada pada kondisi lingkungan yang terganggu akibat adanya gulma dan terjadinya kompetisi antara gulma dan tanaman kedelai sehingga pertumbuhan kedelai terganggu. Menurut Eprim (2006) semakin lama periode bersih gulma maka bobot kering tajuk kedelai akan semakin besar sedangkan semakin lama periode bergulma maka bobot kering tajuk kedelai akan semakin rendah.

Bobot Kering Akar Kedelai
Perlakuan kontrol memberikan pengaruh yang berbeda nyata terhadap bobot kering akar kedelai pada periode bergulma (0-2 MST, 0-6 MST, 0-10 MST, dan 0-panen) (Tabel 5). Gulma bersaing dengan tanaman dengan mengeluarkan senyawa alelopati yang bersifat toksik ke sekitarnya sehingga dapat mengganggu pertumbuhan tanaman disekitarnya terutama mengganggu petumbuhan akar dan perubahan sel akar tanaman. Menurut Soembodo (2010) jarak yang berdekatan antara tanaman dan gulma dapat menyebabkan persaingan terhadap air. Gulma dengan perakaran yang lebih luas dan dalam akan lebih cepat menyerap unsur hara yang tersedia dalam tanah dan semakin menekan pertumbuhan dan perkembangan akar pada tanaman kedelai hitam.

Tabel 5. Bobot kering tajuk dan bobot kering akar kedelai hitam Mallika pada periode kritis pertumbuhan kedelai hitam dalam berkompetisi dengan gulma

\begin{tabular}{lcccccc}
\hline \multirow{2}{*}{ Perlakuan } & \multicolumn{3}{c}{ Bobot kering tajuk } & \multicolumn{3}{c}{ Bobot kering akar } \\
\cline { 2 - 7 } & 4 MST & 8 MST & 12 MST & 4 MST & 8 MST & 12 MST \\
\hline Bersih Gulma 0-panen (kontrol) & 1.69 & 22.10 & 20.74 & 0.22 & 2.76 & 1.24 \\
Bersih Gulma 0-2 MST & 1.09 & 13.78 & 20.97 & 0.30 & 2.00 & 1.43 \\
Bersih Gulma 0-4 MST & 1.61 & 12.42 & 27.13 & 0.11 & 1.89 & 1.81 \\
Bersih Gulma 0-6 MST & 2.04 & 13.78 & 11.05 & 0.07 & 1.66 & 0.89 \\
Bersih Gulma 0-8 MST & 2.59 & 17.34 & 14.88 & 0.19 & 1.62 & 0.75 \\
Bersih Gulma 0-10 MST & 1.54 & 14.60 & 31.06 & 0.38 & 2.20 & 2.13 \\
Bergulma 0-2 MST & 1.93 & 14.11 & 22.63 & 0.10 & $1.30 \mathrm{a}$ & 1.20 \\
Bergulma 0-4 MST & 1.67 & 13.02 & 13.52 & 0.25 & 1.46 & 0.68 \\
Bergulma 0-6 MST & 0.57 & 13.26 & 15.17 & 0.04 & $1.02 \mathrm{a}$ & 1.13 \\
Bergulma 0-8 MST & 0.50 & 14.12 & 8.55 & 0.14 & 1.38 & 0.90 \\
Bergulma 0-10 MST & 1.53 & 13.20 & 6.01 & 0.14 & $1.36 \mathrm{a}$ & 0.89 \\
Bergulma 0-panen & 0.78 & $10.70 \mathrm{a}$ & 9.69 & 0.26 & $1.04 \mathrm{a}$ & 0.42 \\
\hline
\end{tabular}

Keterangan : Angka yang diikuti dengan huruf a berbeda nyata dengan perlakuan bersih gulma 0-panen (kontrol) berdasarkan hasil $T$-dunnett pada taraf $\alpha=5 \%$, MST = minggu setelah tanam.

\section{Jumlah Polong Isi}

Perlakuan kontrol memberikan pengaruh yang berbeda nyata terhadap jumlah polong isi pada periode bergulma (0-6 MST, 0-8 MST, 0-10 MST, dan 0- panen) (Tabel 6). Persaingan antar tanaman dapat mengakibatkan penurunan komponen hasil seperti jumlah polong. Menurut Hendrival et.al (2014) tanaman kedelai yang tumbuh bersama dengan gulma dapat menyebabkan tingkat pertumbuhan tanaman terhambat, daun lebih jarang, serta polong berukuran lebih kecil dibandingkan dengan kedelai yang tumbuh tanpa gulma. Semakin besar populasi gulma dalam area pertanaman kedelai maka akan mengakibatkan semakin tertekannya pertumbuhan dan semakin rendah polong kedelai yang dihasilkan. Menurut Widyatama et.al (2012) gulma yang tumbuh pada areal pertanaman kedelai yang semakin rapat dan lebat akan semakin memperlambat pertumbuhan fase vegetatif yang akan menimbulkan pertumbuhan vegetatif tanaman yang kurang maksimal, akibatnya saat memasuki fase generatif terjadinya penurunan potensi source dan mengakibatkan rendahnya pertumbuhan organ pemakai $(\operatorname{sink})$ seperti polong dan biji.

\section{Jumlah Polong Hampa}

Perlakuan kontrol tidak memberikan pengaruh yang berbeda nyata terhadap jumlah polong hampa pada semua perlakuan periode penyiangan gulma (Tabel 6). Polong hampa pada kedelai dapat diakibatkan dengan adanya serangan hama ulat penggerek polong kedelai (Etiella zinckenella), kepik penghisap polong kedelai (Riptortus linearis) dan kepik hijau (Nezara 
viridula). Menurut Marwoto (2013) periode kritis tanaman kedelai terhadap serangan hama penghisap polong ini adalah pada stadia pengisian polong biji. Serangan yang terjadi pada fase pertumbuhan polong dan perkembangan biji menyebabkan polong dan biji kempis, kemudian mengering dan sering kali menyebabkan polong gugur. Serangan yang terjadi pada fase pengisian biji menyebabkan biji menghitam dan membusuk. Menurut Sembodo (2010) gulma berakibat pada kehilangan hasil dengan cara bersaing dengan tanaman budidaya dimana gulma sebagai inang alternatif dari hama dan penyakit sehingga mereduksi hasil yang mengakibatkan kehilangan hasil.

\section{Bobot 100 Butir}

Perlakuan kontrol tidak memberikan pengaruh yang berbeda nyata terhadap bobot 100 butir pada semua perlakuan periode penyiangan gulma. Bobot 100 butir yang dihasilkan (Tabel 6) berkisar antara 8.65-10.42 g. Menurut Permentan (2007) kedelai hitam memiliki bobot 100 butir sebesar 9-10 g. Bobot 100 butir pada 0-2 MST, 08 MST, dan 0-10 MST berada pada kisaran 8.65 hingga $8.88 \mathrm{~g}$. Berat 100 biji pada periode kompetisi gulma dapat mengalami penurunan hasil kedelai apabila gulma dibiarkan pada areal pertanaman kedelai dari awal tanam hingga panen. Menurut Hendrival et.al (2014) gulma yang tumbuh pada awal pertumbuhan tanaman lebih besar pengaruhnya terhadap berat biji tanaman karena karbohidrat yang dihasilkan dari fotosintesis berkurang. Menurut Hasanuddin
(2012), bobot 100 butir berkaitan besar dengan fotosintat karena sebagian fotosintat ditimbunkan dalam biji. Pemanfaataan faktor sarana tumbuh dapat melakukan aktivitas fotosintesis yang lebih baik.

\section{Bobot Biji Kering}

Perlakuan kontrol memberikan pengaruh yang berbeda nyata terhadap bobot biji kering pada periode bergulma (0-4 MST, 0-6 MST, 0-10 MST, dan 0-panen). Bobot biji kering yang dihasilkan berkisar antara $12.73 \mathrm{~g}$ hingga $94.09 \mathrm{~g}$ (Tabel 6). Areal tanaman kedelai yang bersaing dengan gulma sejak awal pertanaman kedelai memiliki bobot biji kering kedelai yang lebih rendah dibandingkan dengan gulma yang tumbuh setelah beberapa lama munculnya tanaman. Menurut Hendrival et.al (2014) berat bobot biji kering pada periode kompetisi gulma dapat mengalami penurunan hasil kedelai apabila gulma dibiarkan pada areal pertanaman kedelai dari awal tanam hingga panen. Gulma yang tumbuh pada awal pertumbuhan tanaman lebih besar pengaruhnya terhadap berat biji tanaman. Kehadiran gulma pada areal pertanaman kedelai yang tidak dapat dihindarkan dapat mengakibatkan kompetisi antara gulma dan tanaman kedelai. Kemampuan kompetitif antara gulma dan tanaman kedelai sangat tergantung pada kondisi lingkungan. Menurut Knezevic (2002) kemunculan gulma pada areal pertanaman dapat mempengaruhi kehilangan hasil ketika gulma mulai mempunyai tinggi $30 \mathrm{~cm}$ sebesar 10$20 \%$.

Tabel 6. Karakter polong isi, polong hampa, bobot 100 butir, dan bobot biji kering kedelai hitam Mallika pada periode kritis pertumbuhan kedelai hitam dalam berkompetisi dengan gulma

\begin{tabular}{lcccc}
\hline \multicolumn{1}{c}{ Perlakuan } & Polong isi & Polong hampa & Bobot 100 butir (g) & Bobot biji kering (g) \\
\hline Bersih Gulma 0-panen (kontrol) & 696.33 & 68.00 & 10.06 & 92.73 \\
Bersih Gulma 0-2 MST & 295.00 & 31.00 & 9.28 & 94.09 \\
Bersih Gulma 0-4 MST & 523.33 & 44.33 & 9.35 & 75.97 \\
Bersih Gulma 0-6 MST & 596.67 & 87.33 & 9.22 & 91.71 \\
Bersih Gulma 0-8 MST & 533.67 & 84.00 & 9.84 & 93.87 \\
Bersih Gulma 0-10 MST & 408.00 & 50.67 & 9.41 & 78.49 \\
Bergulma 0-2 MST & 563.67 & 97.00 & 8.78 & 67.19 \\
Bergulma 0-4 MST & 411.33 & 67.00 & 9.78 & $58.05 \mathrm{a}$ \\
Bergulma 0-6 MST & $238.67 \mathrm{a}$ & 35.00 & 10.42 & $30.30 \mathrm{a}$ \\
Bergulma 0-8 MST & $103.00 \mathrm{a}$ & 25.33 & 8.65 & $12.73 \mathrm{a}$ \\
Bergulma 0-10 MST & $170.33 \mathrm{a}$ & 69.67 & 8.88 & $22.67 \mathrm{a}$ \\
Bergulma 0-panen & $112.00 \mathrm{a}$ & 48.00 & 9.05 & $24.37 \mathrm{a}$ \\
\hline
\end{tabular}

Keterangan : Angka yang diikuti dengan huruf a berbeda nyata dengan perlakuan bersih gulma 0-panen (kontrol) berdasarkan hasil $T$-dunnett pada taraf $\alpha=5 \%$, MST $=$ minggu setelah tanam. 


\section{Hasil Kedelai Hitam Mallikal.5 $\mathrm{m}^{2}$}

Perlakuan kontrol memberikan pengaruh yang berbeda nyata terhadap hasil ubinan pada periode bersih gulma (0-2 MST dan 0-4 MST) dan periode bergulma (0-4 MST, 0-6 MST, 0-8 MST, 0-10 MST, dan 0-panen). Hasil kedelai hitam Mallika (Tabel 7) berkisar antara 39.84 hingga $242.12 \mathrm{~g}$ dengan periode bersih gulma 0-panen (kontrol) memiliki hasil yang tertinggi dan periode bergulma 0 -panen memiliki hasil yang terendah. Rata-rata hasil tertinggi pada perlakuan kontrol yang diperoleh adalah $242.12{\mathrm{~g} 1.5 \mathrm{~m}^{-2}}^{-2}$
(1.61 ton ha $\left.{ }^{-1}\right)$. Menurut Permentan (2007), kedelai hitam varietas Mallika memiliki rata-rata panen 2.34 ton ha $^{-1}$ dan potensial hasil 2.94 ton ha ${ }^{1}$. Kehilangan hasil yang diperoleh berkisar antara $23.61 \%$ hingga $83.54 \%$. Menurut Lailiyah et.al (2014) gulma bila tidak dikendalikan dapat menurunkan hasil panen berkisar antara 20\% hingga 80\%. Menurut Hendrival et.al (2014) gulma yang tumbuh pada awal pertumbuhan tanaman lebih mempunyai pengaruh yang besar terhadap hasil panen kedelai dibandingkan dengan gulma yang tumbuh setelah beberapa lama munculnya tanaman dengan lama persaingan yang sama.

Tabel 7. Hasil kedelai hitam Mallika $1,5 \mathrm{~m}^{2}$ pada periode kritis pertumbuhan kedelai hitam dalam berkompetisi dengan gulma

\begin{tabular}{lcc}
\hline \multicolumn{1}{c}{ Perlakuan } & Hasil panen $(\mathrm{g})$ & \% kehilangan hasil dibandingkan dengan kontrol \\
\hline Bersih Gulma 0-panen (kontrol) & 242.12 & \\
Bersih Gulma 0-2 MST & $96.11 \mathrm{a}$ & 60.30 \\
Bersih Gulma 0-4 MST & $124.00 \mathrm{a}$ & 48.78 \\
Bersih Gulma 0-6 MST & 180.71 & 25.36 \\
Bersih Gulma 0-8 MST & 181.27 & 25.13 \\
Bersih Gulma 0-10 MST & 184.94 & 23.61 \\
Bergulma 0-2 MST & 181.34 & 25.10 \\
Bergulma 0-4 MST & $114.46 \mathrm{a}$ & 52.72 \\
Bergulma 0-6 MST & $75.33 \mathrm{a}$ & 68.88 \\
Bergulma 0-8 MST & $51.78 \mathrm{a}$ & 78.57 \\
Bergulma 0-10 MST & $48.00 \mathrm{a}$ & 80.17 \\
Bergulma 0-panen & $39.84 \mathrm{a}$ & 83.54 \\
\hline
\end{tabular}

Keterangan : Angka yang diikuti dengan huruf a berbeda nyata dengan perlakuan bersih gulma 0-panen (kontrol) berdasarkan hasil T-dunnett pada taraf $\alpha=5 \%$, MST $=$ minggu setelah tanam.

\section{Persen Penutupan Gulma}

Persen penutupan gulma tertinggi adalah periode bergulma 0-panen karena gulma telah hadir di areal pertanaman kedelai dari awal pertanaman hingga akhir pertumbuhan kedelai (Tabel 8). Semakin lama gulma berada pada areal pertanaman kedelai maka persen penutupan gulma semakin tinggi. Perlakuan periode bergulma 0panen diperoleh bahwa pada 2 MST-6 MST, persen penutupan gulma berlangsung sangat cepat karena tajuk tanaman kedelai belum saling menutupi antara tanaman yang satu dengan yang lainnya. Persen penutupan gulma yang semakin menurun akibat adanya penyiangan gulma dan pertumbuhan gulma semakin lambat karena tajuk tanaman kedelai semakin menutupi areal pertanaman sehingga gulma semakin tertekan.

Persen penutupan gulma yang tetap $(0.00 \%)$ terjadi karena tajuk pertanaman sudah menutupi areal pertanaman sehingga cahaya matahari yang diterima gulma semakin berkurang, akibatnya aktivitas fotosintesis gulma dan pertumbuhan gulma menurun dan pertumbuhan menjadi terhambat, tetapi pada 12 MST (menjelang panen) terjadi peningkatan persen penutupan gulma karena tanaman kedelai daun tanaman kedelai sudah mulai menguning dan rontok yang diakibatkan adanya aktivitas fisiologis kedelai menjelang panen. Menurut Eprim (2006) penutupan tajuk tanaman kedelai semakin berkurang sehingga intensitas cahaya matahari yang diterima gulma semakin besar dan menyebabkan laju pertumbuhan gulma semakin meningkat. Pertumbuhan tanaman yang cepat mampu menutupi permukaan tanah melalui kanopi sehingga intensitas matahari yang diterima gulma semakin sedikit dan memberikan peluang kepada tanaman untuk memanfaatkan cahaya matahari secara optimal.

Gulma yang terdapat pada areal pertanaman kedelai hitam Mallikaadalah golongan rumput yang terdiri atas satu famili yaitu Poaceae (6 spesies), teki terdiri atas satu famili yaitu Cyperaceae (3 spesies), dan daun lebar terdiri atas 14 famili yaitu Asteraceae (3 spesies); Fabaceae (3 spesies); Commelinaceae (2 spesies); Oxalidaceae (1 spesies); Araceae (1 spesies); 
Acanthaceae (1 spesies); Amaranthaceae (2 spesies); Euphorbiaceae (2 spesies); Capparidaceae (1 spesies); Solanaceae (1 spesies); Rubiaceae (3 spesies); Phylanthaceae (1 spesies); Convolvulaceae (1 spesies) dan Loganiaceae (1 spesies). Gulma golongan daun lebar lebih dominan tumbuh dibandingkan dengan gulma golongan rumput dan teki. Menurut Hendrival et.al (2014), famili Asteraceae merupakan famili yang dominan ditemukan di pertanaman kedelai. Spesies gulma yang dominan tumbuh umumnya tergolong gulma dengan siklus hidup kurang dari satu tahun (gulma setahun atau semusim).

Spesies gulma yang mempunyai nilai nisbah jumlah dominan (NJD) di atas nilai rata- rata golongan dinyatakan sebagai spesies yang dominan (Haryatun, 2008). Golongan gulma yang menjadi spesies dominan adalah Rotboellia exaltata $(28.87 \%)$, golongan teki yang menjadi speseies dominan adalah Cyperus rotundus $(2.35 \%)$, sedangkan golongan daun lebar yang menjadi spesies dominan adalah Alternanthera philoxeroides(19.47\%), Synedrella nodiflora (10.09\%), Cleome rutidosperma (5.13\%), Commelina benghalensis (4.05\%), dan Mimosa pudica (2.86\%). Menurut Widayat (2002), gulma golongan daun lebar cenderung dapat menurunkan hasil panen yang lebih besar jika dibandingkan dengan gulma golongan rumput dan teki.

Tabel 8. Persen penutupan gulma pada periode kritis pertumbuhan kedelai hitam dalam berkompetisi dengan gulma

\begin{tabular}{lcccccc}
\hline \multirow{2}{*}{ Perlakuan } & \multicolumn{5}{c}{ Persen Penutupan Gulma } \\
\cline { 2 - 7 } & 2 MST & 4 MST & 6 MST & 8 MST & 10 MST & 12 MST \\
\hline Bersih Gulma 0-panen (kontrol) & 11.67 & 1.67 & 0.00 & 0.00 & 0.00 & 1.67 \\
Bersih Gulma 0-2 MST & 14.33 & $51.67 \mathrm{a}$ & $85.00 \mathrm{a}$ & $95.00 \mathrm{a}$ & $71.67 \mathrm{a}$ & $80.00 \mathrm{a}$ \\
Bersih Gulma 0-4 MST & 10.00 & 0.33 & $41.67 \mathrm{a}$ & $51.67 \mathrm{a}$ & $51.00 \mathrm{a}$ & $63.33 \mathrm{a}$ \\
Bersih Gulma 0-6 MST & 11.00 & 1.33 & 0.00 & $10.00 \mathrm{a}$ & 0.00 & $21.67 \mathrm{a}$ \\
Bersih Gulma 0-8 MST & 11.00 & 1.33 & 0.00 & 0.00 & 0.00 & $11.67 \mathrm{a}$ \\
Bersih Gulma 0-10 MST & 12.00 & 1.00 & 0.00 & 0.00 & 0.00 & 0.00 \\
Bergulma 0-2 MST & $73.33 \mathrm{a}$ & 1.67 & 0.00 & 0.00 & 0.00 & 1.67 \\
Bergulma 0-4 MST & $73.00 \mathrm{a}$ & $98.67 \mathrm{a}$ & 0.00 & 0.00 & 0.00 & 5.00 \\
Bergulma 0-6 MST & $64.33 \mathrm{a}$ & $97.00 \mathrm{a}$ & $100.00 \mathrm{a}$ & 0.00 & 0.00 & 5.00 \\
Bergulma 0-8 MST & $66.67 \mathrm{a}$ & $97.33 \mathrm{a}$ & $100.00 \mathrm{a}$ & $100.00 \mathrm{a}$ & 0.00 & 3.33 \\
Bergulma 0-10 MST & $57.33 \mathrm{a}$ & $98.33 \mathrm{a}$ & $100.00 \mathrm{a}$ & $100.00 \mathrm{a}$ & $100.00 \mathrm{a}$ & 6.00 \\
Bergulma 0-panen & $75.00 \mathrm{a}$ & $98.33 \mathrm{a}$ & $100.00 \mathrm{a}$ & $100.00 \mathrm{a}$ & $100.00 \mathrm{a}$ & $100.00 \mathrm{a}$ \\
\hline
\end{tabular}

Keterangan : Angka yang diikuti dengan huruf a berbeda nyata dengan perlakuan bersih gulma 0-panen (kontrol) berdasarkan hasil T-dunnett pada taraf $\alpha=5 \%$, MST = minggu setelah tanam.

\section{Periode Kritis Tanaman Kedelai dalam Bersaing Dengan Gulma}

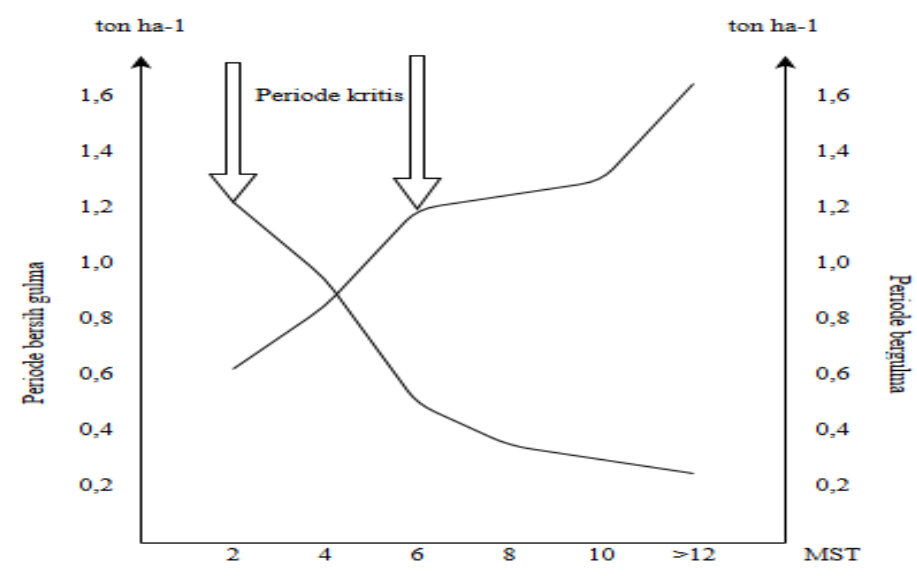

Gambar 1. Periode kritis tanaman kedelai hitam Malika dalam persaingan dengan gulma

Perlakuan kontrol memberikan hasil yang berbeda nyata terhadap perlakuan bersih gulma(02 MST dan 0-4 MST) sehingga gulma harus dikendalikan sejak awal tanam hingga 6 MST agar hasilnya tidak berbeda nyata dengan kontrol.
Hasil periode bersih gulma 0-panen memberikan pengaruh yang berbeda nyata terhadap periode bergulma (0-4 MST, 0-6 MST, 0-8 MST, 0-10 MST, dan 0-panen). Hal ini menunjukkan bahwa gulma akan menurunkan hasil terhadap kedelai 
hitam Mallika pada periode bergulma 0-4 MST sehingga gulma harus dikendalikan dari awal tanam hingga 2 MST agar hasil tidak berbeda nyata terhadap kontrol. Oleh karena itu, periode kritis tanaman kedelai hitam Mallika adalah 2-6 MST sehingga penyiangan gulma dapat dilakukan 2 MST hingga 6 MST agar tidak menimbukan kehilangan hasil secara nyata. Kehilangan hasil panen dari awal tanam hingga panen diperoleh berkisar antara $23.61 \%$ hingga $83.77 \%$. Periode bersih gulma yang semakin lama akan mengakibatkan semakin tingginya hasil panen kedelai sedangkan semakin periode bergulma dalam areal pernanaman akan mengakibatkan semakin menurunya hasil panen.

Hubungan antara periode bersih gulma dan periode bergulma terhadap komponen hasil kedelai menunjukkan hubungan yang menggambarkan bahwa periode bersih gulma yang semakin lama maka semakin tinggi nilai komponen hasil kedelai, demikian juga sebaliknya. Oleh karena itu, komponen hasil kedelai dapat menentukan suatu periode kritis tanaman sehingga dapat diketahui kapan saat yang tepat untuk mengendalikan gulma dan tindakan yang tepat dilakukan untuk pengelolaan gulma sehingga tidak menimbulkan kerugian hasil.

\section{KESIMPULAN}

Periode penyiangan gulma memberikan pengaruh yang berbeda nyata terhadap jumlah daun, jumlah cabang, waktu berbunga, bobot kering tajuk tanaman, bobot kering biomassa tanaman, jumlah polong isi, bobot biji kering, dan hasil kedelai hitam $1.5 \mathrm{~m}^{2}$, namun tidak memberikan pengaruh yang berbeda nyata terhadap tinggi tanaman, indeks luas daun, jumlah polong hampa, dan bobot 100 biji. Periode kritis tanaman kedelai hitam varietas Mallika adalah 2-6 MST. Hasil panen tertinggi adalah saat periode bersih gulma 0 -panen yaitu $242.12 \mathrm{~g} 1,5 \mathrm{~m}^{-2}$ (1.61 ton $\mathrm{ha}^{-1}$ ) dan hasil terendah pada saat bergulma 0 -

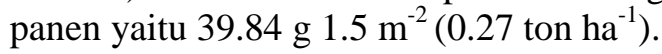

\section{DAFTAR PUSTAKA}

Adie, M.M., Krisnawati, A. 2007. Biologi tanaman kedelai. hal 45-73. Dalam Sumarno. Suyanto A. Widjono.

Hermanto. dan Kasil H (Eds). Kedelai. Teknik Produksi dan Pengembangan Pertanian. Badan Penelitian dan Pengembangan Pertanian. Bogor.

[BKPP] Balai Ketahanan Pangan dan Penyuluh Pertanian. 2009. Budidaya tanaman kedelai. Balai Pengkajian Teknologi Pertanian. Nanggroe Aceh Darussalam.

[BMKG] Badan Meteorologi Klimatologi dan Geofisika. 2016. Data iklim tahun 2016. Stasiun Klimatologi Dramaga. Bogor.

Eprim, Y.S. 2006. Periode kritis tanaman kedelai (Glycine $\max$ (L.) Merr.) terhadap kompetisi gulma pada beberapa jarak tanam di lahan alang-alang. Skripsi. Institut Pertanian Bogor. Bogor.

Haryatun. 2008. Teknik identifikasi jenis gulma dominan dan status ketersediaan hara nitrogen, fosfor, dan kalium beberapa jenis gulma di lahan rawa lebak. Buletin Teknik Pertanian. 13 (1) : 1922.

Hasanuddin. 2012. Pengaruh persaingan gulma Synedrella nodiflora L. Gaertn. pada berbagai densitas terhadap pertumbuhan hasil kedelai. Jurnal Agrista. 16 (3):146-152.

Hendrival, Wirda, Z., Azis, A. 2014. Periode kritis tanaman kedelai terhadap persaingan gulma. Jurnal Floratek. 9: $6-13$.

Inawati, L. 2000. Pengaruh jenis gulma terhadap pertumbuhan. pembentukan bintil akar dan produksi varietas kedelai. Skripsi. Jurusan Budidaya Pertanian.Institut Pertanian Bogor. Bogor.

[PERMENTAN] Keputusan Menteri Pertanian. 2007. Pelepasan galur kedelai hitam lokal Mallika sebagai varietas unggul dengan nama Mallika. Jakarta.

Knezevic. 2002. Critical period for weed control: the concept and data analysis. Journal of Weed Science. 50:773-786.

Lailiyah, W.N., Eko, W., Karuniawan, P.W. 2014. Pengaruh periode penyiangan gulma terhadap pertumbuhan dan hasil tanaman kacang panjang (Vigna sesquipedalis L.). Jurnal Produksi Tanaman. 2 (7) : 606-612.

Manshuri, A.G. 1995. Keragaman karakter morfofisiologi beberapa varietas kedelai dalam hubunganya dengan akumulasi bobot kering tanaman dan 
potensi hasil. Disertasi. Institut Pertanian Bogor. Bogor.

Marwoto. 2013. Hama. penyakit. dan masalah hara pada tanaman kedelai : indentifikasi dan pengendaliannya. Balai Penelitian dan Pengembangan Tanaman Pangan. Jakarta.

Moenandir, J. 2010. Ilmu Gulma Cetakan I. Malang(ID): Universitas Brawijaya Press.

Sembodo, D.R.J. 2010. Gulma dan Pengelolaannya Edisi Pertama. Yogyakarta(ID): Graha Ilmu.

Sumarno, Manshuri, A.G. 1999. Teknik Pemuliaan Kedelai. hal 263-294. Dalam
Somaatmadja. S.. M. Ismunadji

Sumarno. M. Syam. S. O Manurung dan Yuswadi. (Eds). Kedelai. Balai Penelitian dan Pengembangan Pertanian. Pusat Penelitian dan Pengembangan Tanaman Pangan. Bogor.

Widayat, D. 2002. Kemampuan berkompetisi kedelai (Glycine max), kacang tanah (Arachis hypogoea) dan kacang hijau (Vigna radiata) terhadap teki (Cyperus rotundus). Jurnal Agrista. 4(2) : 118128.

Widyatama, C.E., Tohari, Rogomulyo R. 2012. Periode kritis kedelai hitam (Glycine max (L.) Merr) terhadap gulma. Skripsi. Universitas Gadjah Mada. Yogyakarta. 